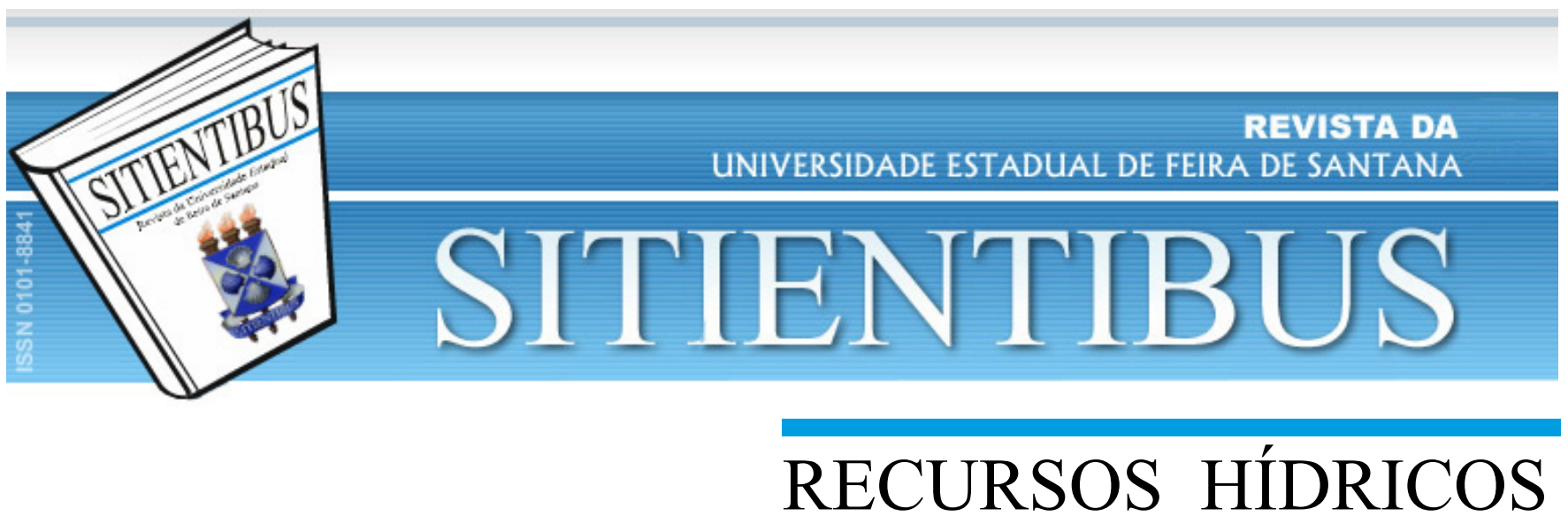

ARTIGO

\title{
BACIA HIDROGRÁFICA DO RIO JACUÍPE: INFLUÊNCIA DE CIDADES DO MÉDIO CURSO NO PROCESSO DE DEGRADAÇÃO AMBIENTAL
}

\section{JACUÍPE RIVER WATER BASIN: INFLUENCE OF MIDDLE COURSE CITIES IN THE ENVIRONMENTAL DEGRADATION PROCESS}

\author{
Oriana ARAUjo \\ Mestra em Ciências Ambientais. Professora Assistente do curso de Geografia (DCHF/UEFS). E-Mail: orianageo@gmail.com
}

\section{RESUMO}

O objetivo desse texto é examinar a influência das cidades situadas no médio curso da bacia do rio Jacuípe no processo de desmatamento a partir da retirada da cobertura vegetal, com consequente exposição dos solos aos processos erosivos. Para isso, utilizou-se imagens de satélite, técnicas de processamento digital de dados e de modelagem espacial, a fim de verificar o percentual total da cobertura vegetal até $5 \mathrm{~km}$ das sedes urbanas, bem como da distribuição da cobertura vegetal em círculos projetados a cada km em um mapa de distâncias (buffers). Realizou-se uma pesquisa acerca do processo de ocupação dos municípios, coletando-se dados de população absoluta desde a década de 1970, bem como do avanço das principais atividades agropecuárias: o sisal e o gado bovino, para entender como tal processo articula-se aos processos de desmatamento presentes na área estudada. Constatou-se que há percentuais variados de desmatamento, desde $3 \%$ a $24 \%$ de cobertura vegetal dentre as cidades pesquisadas e seu entorno. Na média, há $11 \%$ de cobertura vegetal nas cidades do médio Jacuípe pesquisadas, o que denota um alto grau de retirada da vegetação. $O$ tamanho das cidades ou sua existência há mais ou menos tempo não são condicionantes do desmatamento ou da manutenção da vegetação, conforme evidenciaram os dados. Outrossim, os municípios com tendência ao avanço da pecuária bovina apresentaram maiores variações na cobertura vegetal, com saldos mais negativos, especialmente Pé de Serra, Gavião, Nova Fátima e Riachão do Jacuípe, enquanto Capela do Alto Alegre e São José do Jacuípe vêm recuperando sua cobertura vegetal devido ao crescimento da algaroba (prosopis juliflora), que pode concorrer com a caatinga, promovendo-lhe fortes danos. Já nos municípios de Valente, Retirolândia e São Domingos, com tendência ao avanço dos sisalais, a cobertura vegetal manteve-se um pouco acima da média, indicando que essa atividade (nesse caso) é menos degradadora que as pastagens.

Palavras-Chave: Rio Jacuípe, desmatamento, caatinga, cidades pequenas, Bahia.

\section{ABSTRACT}

The purpose of this text is to exame the influence of cities located in the middle course of the Jacuípe River basin in the process of deforestation due to the vegetal cover removal, with consequent soil exposure to erosive processes. Satellite imagery, digital data processing and spatial modeling techniques were used in order to verify the total percentage of vegetation cover up to $5 \mathrm{~km}$ from urban centers, as well as the distribution of vegetation cover in circles projected every $\mathrm{km}$ on a map of distances (buffers). A research about the process of ocupation of counties was carried out, collecting data of the absolute population since the 1970s, as well as the advance of the main agricultural activities: sisal and livestock, to understand as such process articulates to the processes of deforestation present in the studied area. It was found percentages of deforestation, from $3 \%$ to $24 \%$ of vegetation cover among the cities surveyed and their environment. On average, there is $11 \%$ of vegetation cover in the cities of the middle Jacuípe researched, which indicates a high degree of vegetation removal. The size of cities or their time of existence are not conditioning of deforestation or maintenance of vegetation, as evidenced by the data. Also, the cities with trend towards livestock presented greater difference in the vegetal cover, with more negative balances, especially Pé de Serra, Gavião, Nova Fátima and Riachão do Jacuípe, while Capela do Alto Alegre and São José do Jacuípe have been recovering their vegetation cover due to the growth of the algaroba (prosopis juliflora), which can compete with the caatinga, promoting it strong damage. On the other hand, in the cities of Valente, Retirolândia and São Domingos, with a tendency to advance the sisalais, the vegetal cover remained slightly above average, indicating that this activity (in this case) is less degrading than pastages.

Keywords: Jacuípe river, deforestation, caatinga, small cities, Bahia. 


\section{BACIA DO RIO JACUÍPE: DOS JACUS, RIO ENXUTO}

Rio Jacuípe (Jacuhy, jacu-y) significa 'rio dos Jacus', e pode também proceder de Yacui, o "rio enxuto" ou "rio temporário" (IBGE, 2010).

O jacu (Penelope superciliaris) é uma ave emblemática, ao ponto de em alguns municípios pesquisados no médio Jacuípe, o grupo político vencedor das eleições ser chamado de carcará (Polyborus plancus) que é um gavião; e o grupo derrotado nas eleições ser chamado de jacu - o que denota a facilidade que se tinha de abater essas aves. Hoje, é cada vez mais raro encontrar o jacu no médio Jacuípe.

O nome dado ao rio demonstra a perspicácia e o conhecimento indígena sobre a natureza, já que sabiam da interrupção do fluxo d'água do rio 'enxuto/temporário', que persiste até os dias atuais.

Considerando-se o leito principal, o rio Jacuípe perfaz aproximadamente $320 \mathrm{~km}$ da nascente à foz e percorre com sua rede de drenagem 39 municípios. A bacia do Jacuípe é bastante extensa no sentido longitudinal, visto que seu curso superior - área de nascentes - localiza-se no município de Morro do Chapéu-BA, seu médio curso atravessa diversos municípios do sertão baiano e sua foz encontra-se em Feira de Santana-BA, no lago de Pedra do Cavalo.

Devido à sua extensão, e considerando-se a multiplicidade de aspectos que envolvem a análise ambiental, fez-se necessário um recorte espacial de análise, de forma que se escolheu, a partir de múltiplos critérios descritos em Araujo da Silva (2010), o médio curso para a realização da pesquisa. O médio curso do Jacuípe perfaz uma área de $4.633,966 \mathrm{~km}^{2}$, correspondente a $38 \%$ da área total da bacia hidrográfica do rio Jacuípe, sendo caracterizado pela intermitência do curso d'água do rio Jacuípe.

No médio curso, o rio Jacuípe e seus principais afluentes atravessam as cidades de São José do Jacuípe, Gavião e Riachão do Jacuípe (cujas sedes são ribeirinhas), além de Capela do Alto Alegre, Pé de Serra, São Domingos, Nova Fátima, Valente, Retirolândia e Conceição do Coité. Os limites são diferentes, haja vista o fato de que as bacias hidrográficas são delimitadas por condicionantes naturais, enquanto os limites municipais advêm de decisões políticoadministrativas, de modo que um município pode ter área territorial em várias bacias hidrográficas, o que dificulta os processos de gestão de bacias, que precisam atender essas especificidades.

Esse texto apresenta o resultado de uma investigação acerca da influência das áreas urbanas como indicador de degradação ambiental no processo de retirada da cobertura vegetal no médio curso da bacia do Rio Jacuípe na Bahia, além de indicar outros problemas ambientais. O estudo mais abrangente constatou que a o médio curso do Jacuípe está sob forte risco de degradação ambiental, haja vista a baixa existência de cobertura vegetal nessa área (Figura 01) e as cidades foram um dos fatores considerados na análise, constatando-se que: "A susceptibilidade à degradação ambiental no médio Jacuípe foi estimada em 5 níveis: alta (80\%), moderadamente alta ( $2 \%)$, intermediária (3\%), moderadamente baixa (4\%) e baixa (11\%)" (ARAUJO DA SILVA, 2010, p. 156).

De acordo com a publicação do Ministério do Meio Ambiente (MMA) organizada por Silva et al. (2004), as áreas florestadas de caatinga, sofreram forte desvalorização ao longo da história, devido ao mito de que a caatinga é um bioma pobre, homogêneo e pouco alterado. $\mathrm{O}$ autor indicou que:

Esses três mitos podem agora ser considerados superados, pois a Caatinga não é homogênea; é sim extremamente heterogênea e inclui pelo menos uma centena de diferentes tipos de paisagens únicas.

A biota da Caatinga não é pobre em espécies e em endemismos, pois, apesar de ser ainda muito mal conhecida, é mais diversa que qualquer outro bioma no mundo, o qual esteja exposto às mesmas condições de clima e solo. Enfim: a Caatinga não é pouco alterada; está entre os biomas brasileiros mais degradados pelo homem (SILVA et al., 2004, p. 9).

O médio curso do Jacuípe corresponde a uma área core do semiárido baiano, com índices pluviométricos anuais inferiores a $700 \mathrm{~mm}$, cujos períodos secos são prolongados, mas, contraditoriamente é bem povoado, o que significa dizer que a sociedade utiliza esse espaço para a prática de suas atividades econômicas e culturais.

Ao discutir a problemática da pressão antrópica, Sousa (2003) considerou que:

O antropismo é caracterizado por toda e qualquer interferência do homem na natureza. Em regiões semi-áridas esta situação é agravada, uma vez que, sob condições hidroclimáticas desfavoráveis, são mais pronunciados os efeitos de qualquer ação e mais difícil o processo de recuperação. (SOUSA, 2003, p. 31)

Na concepção de Almeida (1994), o processo de degradação dos recursos naturais está intimamente relacionado às atividades do setor primário. A respeito do desmatamento, foi taxativo:

O desmatamento tem efeitos gravíssimos sobre o meio ambiente, porque são as florestas responsáveis por diversas funções essenciais para a preservação dos ecossistemas, quais sejam controle da fauna, regime das águas, variação do clima, além de fornecer matéria-prima, controlar a poluição atmosférica e servir de lazer (ALMEIDA, 1994, p. 65).

A combinação desses fatores, associados ao fato de se tratar de uma área de ocorrência de caatinga savana-estépica florestada, savana-estépica arborizada e savana-estépica gramíneo-lenhosa (IBGE, 1992), que é um bioma unicamente brasileiro, rico em endemismos e pouco conservado legalmente, apontam a relevância dessa pesquisa para o entendimento do processo de degradação ambiental do médio Jacuípe. 


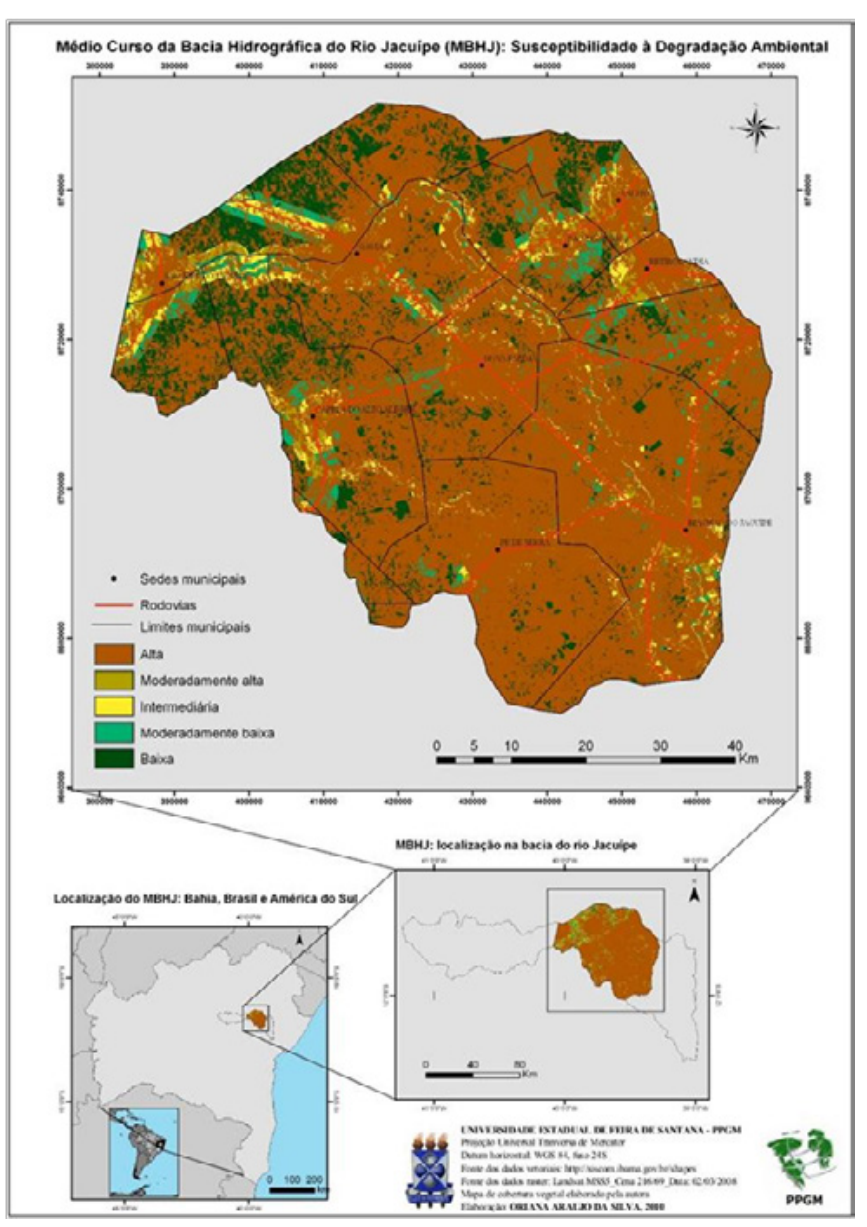

Figura 01. Susceptibilidade à degradação ambiental no médio curso da Bacia Hidrográfica do Rio Jacuípe.

Fonte: Araujo da Silva (2010, p. 148).

\section{Bacias hidrográficas - unidades espaciais de análise}

A Terra, enquanto planeta vivo, constitui-se de elementos bióticos e abióticos que trocam dinamicamente energia e matéria. Da interação entre a litosfera (rochas, solos), a atmosfera (clima), a biosfera (fauna, flora), a noosfera (homem) e a hidrosfera (água - oceanos, lagos e rios), resultam as feições e aspectos que constituem as paisagens (STRAHLER e STRAHLER, 1989; TRUSOV, 1969, citado por GREGORY, 1992).

Nesse sentido, as bacias hidrográficas constituem-se num importante recorte espacial de análise, devido à sua continuidade espacial delimitadas pelas formas da superfície, bem como pelo fato de estarem diretamente relacionadas a todos os demais elementos e processos do sistema natural da Terra.

A água é um elemento natural fundamental à vida no planeta e um dos fatores responsáveis pela morfogênese e pedogênese, influenciando, portanto, o tipo de vegetação que se constituirá em determinados espaços. A relação humana com a água é antiga, bem como o interesse por compreender seus mecanismos de distribuição sobre o planeta.

Além disso, as bacias hidrográficas, notadamente seus rios principais, são utilizados pela sociedade, sendo às vezes condicionantes da presença ou ausência do homem em determinados espaços. Da mesma forma, as bacias hidrográficas são sistemas naturais que comumente sofrem processos de degradação ambiental variados, a exemplo da erosão dos solos, assoreamento dos leitos dos rios e contaminação das águas.

Pode-se considerar que os rios são fluxos de água contínuos (perenes), intermitentes (que secam em alguns períodos do ano) ou efêmeros (que possuem fluxo corrente apenas no período das chuvas). O rio Jacuípe é um rio intermitente e seus principais afluentes são intermitentes e efêmeros.

As águas movem-se sob ação da gravidade, para uma área de relevo mais rebaixado, o nível de base geral, que pode ser um lago, um mar continental ou o oceano. Para atingir o nível de base, o rio entalha o relevo e encaixase nas estruturas menos resistentes das rochas - fraturas (diáclases, fissuras). Nesse processo, o rio tende a entalhar o próprio leito, aprofundando o ponto mais baixo do leito, denominado talvegue, e acaba por se tornar também o nível de base geral para outros cursos d'água que percorrem eixos (direções) opostos ao do canal principal. Assim, os demais rios (fluxos d'água) delimitados por divisores d'água tornam-se afluentes do rio principal, depositando no seu leito a vazão hídrica e sedimentos diluídos e transportados no fluxo d'água. Portanto, a rede hídrica se estabelece e constitui uma bacia hidrográfica que, conforme sua definição geomorfológica, corresponde a uma área drenada por um rio principal e seus afluentes e subafluentes, ou, um conjunto de canais fluviais interligados, que possuem um nível de base local e regional comuns. Seus limites correspondem às áreas onde ocorrem cotas altimétricas mais elevadas, que são os divisores d'água.

A Figura 02 demonstra o Modelo Digital do Terreno a partir das cotas altimétricas no médio Jacuípe, evidenciando o predomínio das baixas altitudes típicas do pediplano sertanejo, com predominância de altitudes variando entre $247 \mathrm{~m}$ a $328 \mathrm{~m}$ e a ocorrência dos pedimentos retocados por drenagem incipiente, resultantes do trabalho erosivo decorrente da intermitência e efemeridade dos cursos d'água da bacia do rio Jacuípe em todo o seu médio curso.

No que tange à questão de que o modelado é pouco dissecado, no caso do médio Jacuípe, deve-se considerar que a pedogênese tem sido dificultada pela retirada da cobertura vegetal natural dos solos, favorecendo os processos erosivos, de modo que há tendência de perdas de nutrientes e de solos agricultáveis, bem como da "exumação" do Embasamento Cristalino.

Sabe-se que a cobertura vegetal favorece a pedogênese, uma vez que possibilita a infiltração das águas e promove o intemperismo químico, grande responsável pela formação dos solos e que, associado a isso, os microorganismos, que também ajudam a desenvolver os solos, não se estabelecem em áreas desnudadas. 


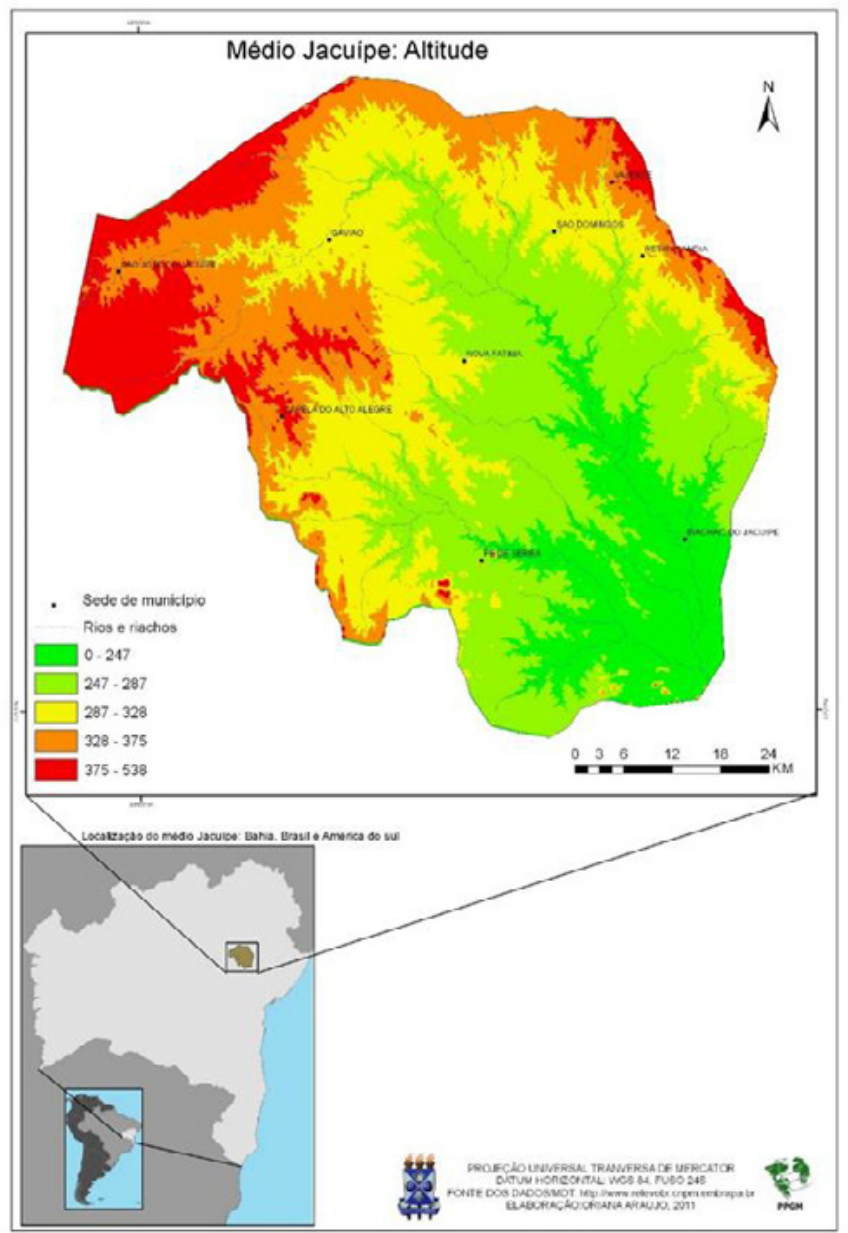

Figura 02 . Cotas altimétricas do Médio Jacuípe.

O pediplano sertanejo, no médio Jacuípe, devido a razões naturais (clima semiárido) e antrópicas (retirada da vegetação natural), está numa fase posterior à do aplainamento, que se caracteriza pela deposição de sedimentos, uma vez que a exumação do Embasamento Cristalino fundase na erosão, num processo de dissecação do relevo.

Um dos principais problemas decorrentes da degradação do ambiente no médio Jacuípe é a perda de nutrientes do solo, que resulta da retirada da cobertura vegetal e exposição dos solos aos processos erosivos. Observa-se que nos períodos de estiagem prolongada as pastagens possuem o aspecto demonstrado na Figura 03.

Aproximando-se do que Guerra (2007) discutiu sobre a erosão, sabe-se que a área estudada, devido ao caráter de intermitência e torrencialidade das chuvas, associadas à presença de argilas, é propensa à erosão laminar, uma vez que a velocidade que o fluxo adquire possibilita não apenas a desagregação e solubilização de minerais, como também o seu transporte, processo esclarecido por Guerra e Botelho (1998, p.18): “[...] os agregados vão preenchendo os poros da superfície do solo, provocando a selagem e a consequente diminuição da porosidade, o que aumenta o escoamento das águas."

Nota-se que o problema da erosão no sertão não pode ser superestimado, para que se busque a promoção da educação ambiental, com vistas à adoção de técnicas que visem à conservação dos solos e do ambiente, ao invés da exumação do substrato rochoso adjacente.

Ressalta-se que apesar da área do médio Jacuípe ser bastante aplainada, existem vários micro-divisores d'água que direcionam os fluxos hídricos, com potencialidade de transporte dos minerais atrelada à torrencialidade das chuvas. Essa assertiva pode ser comprovada pelo fato de os proprietários de terra aproveitarem os períodos de estiagem prolongada, em que os tanques (reservatórios) secam, para limpá-los, ou seja, removerem o material que foi transportado e depositado nos tanques durante o período chuvoso. Claro está que fazem esse procedimento estrategicamente para evitar o assoreamento dos reservatórios.

Uma bacia hidrográfica não pode ser pensada apenas a partir dos processos que ocorrem no leito principal, mas sim na interrelação com os demais elementos do sistema natural que atuam na área da bacia, concluindo que:

\begin{abstract}
Portanto, qualquer dano que aconteça numa bacia hidrográfica vai ter conseqüências diretas ou indiretas sobre os canais fluviais. Os processos de erosão dos solos, bem como movimentos de massa, vão fazer com que o escoamento superficial transporte os sedimentos oriundos desses danos ambientais para algum tipo de rio que drena a bacia. (...) Isso tem causado o assoreamento dos rios e também dos reservatórios construídos para produção de energia hidrelétrica, bem como os açudes, para obtenção de água, em especial nos períodos de seca (ARAúJO et al., 2008, p. 59).
\end{abstract}

Nesse sentido, conhecer a interferência que as cidades situadas sob as bacias hidrográficas do semiárido nordestino provocam, mesmo que a partir da análise da retirada ou manutenção da cobertura vegetal de seu entorno imediato, auxiliará no conhecimento acerca das dinâmicas urbanas e sua articulação rural na exposição dos solos que é fator fundamental para o avanço dos processos erosivos decorrentes das chuvas torrenciais características do clima semiárido.

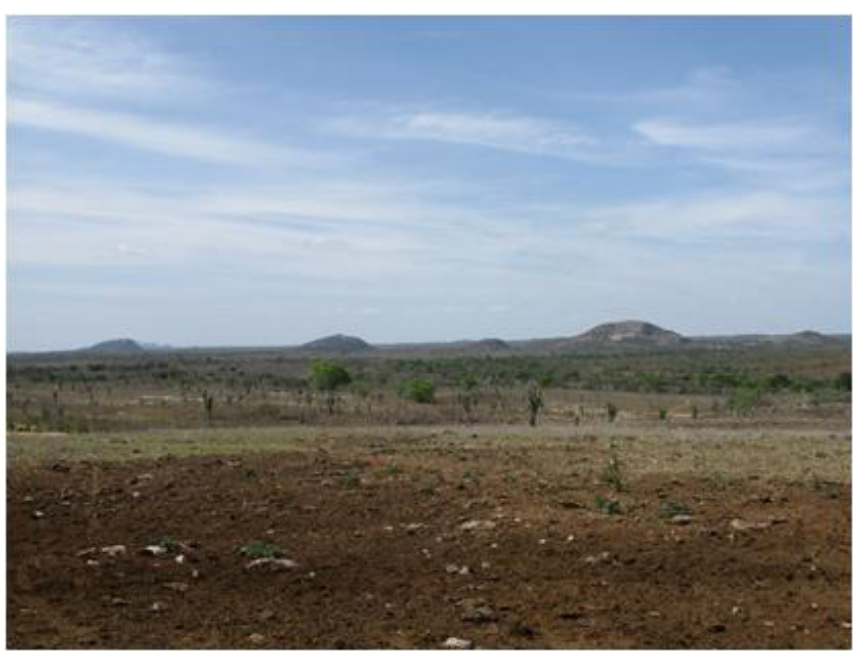

Figura 03. Aspecto de pastagem degradada em ano seco. Município de Gavião-BA (2010). 


\section{Abordagem metodológica: Sensoriamento Remoto na} análise da influência de sedes urbanas

Ao tratar da cognoscibilidade do planeta, Santos (2002) foi enfático ao afirmar que o atual período possibilitará o conhecimento extensivo e aprofundado do planeta, devido à evolução técnico-científica:

[...] os satélites que fotografam o planeta a intervalos regulares, permitindo uma visão mais completa e detalhada da Terra. Por meio dos satélites passamos a conhecer todos os lugares e a observar os astros. [...] Isso não quer dizer que tenhamos, assim, os processos históricos que movem o mundo, mas ficamos mais perto de identificar momentos dessa evolução. Os objetos retratados nos dão geometrias, não propriamente geografias, porque nos chegam como objetos em si, sem a sociedade vivendo dentro deles. (SANTOS, 2002, p. 32).

O autor alertou ainda para a importância da análise, na busca de não "coisificar" algo que é um objeto histórico, por isso de grande valor, já que contém o movimento da sociedade.

O sensoriamento remoto é uma técnica de obtenção de dados sobre a superfície terrestre, sem contato direto com os alvos, a partir do registro de suas características espectrais, de acordo com Jensen et al. $(1989,2007)$, Lillesand \& Kiefer (2008) e Novo $(1995,2008)$.

Consiste na captura da resposta eletromagnética que os elementos naturais e artificiais emitem, quando submetidos a uma fonte de energia, a exemplo do sol, ou quando essa fonte cessa. Para Mustard e Sunshine (1999, p. 252): "Em geral, a reflectância é definida como a razão da intensidade da radiação eletromagnética dispersa da superfície pela intensidade da radiação incidente sobre ela". Assim, cada elemento da superfície da Terra pode ser identificado a partir da análise da resposta espectral em cada comprimento de onda que constitui as imagens digitais provenientes de sensores imageadores.

Dessa forma, uma imagem de sensoriamento remoto não consiste numa fotografia simples do planeta, uma vez que há os princípios físicos e matemáticos em sua composição, que possibilita a extração de informações, obtidas com o Processamento Digital das Imagens (PDI). Esse processo é possível porque a atmosfera possui "janelas" (LILLESAND \& KIEFER, 2008), que são faixas em que não há bloqueio para a transmissividade da resposta eletromagnética. Os sensores instalados nas plataformas dos satélites são calibrados então para capturar essa resposta, razão pela qual há as bandas ou faixas do espectro eletromagnético especificadas para cada tipo de satélite (JENSEN, 2007).

O resultado é uma matriz numérica, contendo os níveis de cinza ou número digital de cada pixel, que é a menor unidade imageada pelo sensor (CRÓSTA, 1992). Essa matriz é passível de uma série de aplicações estatísticas que possibilita a extração, classificação e mapeamento das informações contidas, dentre outras funções que são executadas a par- tir do Processamento Digital de Imagens, considerando-se que os diferentes alvos (vegetação, solo, rocha, água, etc.), possuem assinaturas espectrais diferenciadas, refletindo mais ou menos energia (radiância) em cada comprimento de onda.

O sensoriamento remoto e o processamento digital de imagens permitem acompanhar os processos que ocorrem na superfície terrestre, tanto em variada escala temporal, como espacial, conforme destacou Drury (1990), o que os torna extremamente importantes para o conhecimento das feições adquiridas pelos objetos naturais e artificiais que compõem os diferentes espaços geográficos.

$\mathrm{Na}$ concepção de Liu (2006, p. 03) "O satélite é uma máquina fantástica que possui lentes em vários comprimentos de onda eletromagnética e vigia cada pedaço do planeta Terra para informar rapidamente e minuciosamente o que está acontecendo nele (...)", o que demonstra a vasta perspectiva aberta às diversas ciências com o uso do sensoriamento remoto.

Optou-se por utilizar o processamento digital de imagens, balizado por trabalhos de campo, que possiblitaram o conhecimento da área e a delimitação de amostras confiáveis para o processamento digital e estabelecimento do tipo de cobertura vegetal do médio Jacuípe. Os materiais utilizados para a realização desse trabalho foram:

- Software ArcGis 9.3; Envi 4.6;

- Imagens Landsat MSS1, MSS3 e Landsat TM5 (Cena 216/68, de 03/02/2008), adquiridas junto ao INPE, gratuitamente, via pedido on-line à Divisão de Gerenciamento de Imagens (DGI)';

- Dados digitais temáticos disponibilizados em: http://siscom.ibama.gov.br/shapes;

- Modelo Digital de Terreno disponibilizado em: http://www.relevobr.cnpm.embrapa.br;

- Aparelho GPS (Global Position System).

Os métodos utilizados foram os seguintes:

i. Levantamento bibliográfico e elaboração de referencial teórico;

ii. Pré-processamento e processamento digital de imagens (recorte, reamostragem, composição colorida, classificação supervisionada, NDVI, edição);

iii. Trabalhos de campo;

iv. Organização do banco de dados (ajuste de similaridade de datuns e escala, exportação para os formatos específicos de cada software e procedimento realizado);

v. Elaboração de mapas de distância (buffers) para sedes de municípios, estradas e rios principais;

vi. Cálculo de áreas de cobertura vegetal em cada distância considerada para as variáveis sedes de municípios, estradas e rios principais;

vii. Elaboração de mapas temáticos e edição;

viii. Análise e integração dos resultados.

\footnotetext{
${ }^{1}$ Através do endereço: www.dgi.inpe.com.br.
} 
Médio Jacuípe: ocupação inicial e atividades agrícolas predominantes

A ocupação do sertão se deu a partir do avanço da pecuária, "liberando" as terras férteis da Zona da Mata para o plantio de cana-de-açúcar. $O$ avanço da criação de gado para o interior da Bahia deu-se com o estabelecimento de grandes fazendas no sertão, destinadas à criação de gado. Nesse período, a figura do tropeiro - o negociante (ou criador), que conduzia as tropas bovinas criadas no sertão para a comercialização em cidades prósperas, no litoral, ou no agreste, a exemplo de Salvador, Cachoeira e Feira de Santana era marcante e daí resultam relatos acerca da existência de uma caatinga densa, fechada, que "impedia" a chegada do "progresso".

A respeito do processo histórico de ocupação dessa área o IBGE (2010) destaca o processo de cessão de terras no período colonial e estratégia de ocupar o sertão com a pecuária bovina, que possibilitava o domínio de faixas amplas de terra com uso mínimo de mão de obra:

A casa da ponte era o centro de uma propriedade de 160 (cento e sessenta) léguas do morro do chapéu até o rio das Velhas e pertencia a Antônio Guedes Brito, primeiro Conde da Ponte. Era doação do rei de Portugal em retribuição aos serviços prestados por seu pai na expulsão dos holandeses e a ele mesmo, concedendo-lhe o título de Mestre de Campo e Regente do São Francisco. Ele deveria expulsar ladrões de gados, contrabandista de ouro, negros aquilombados e outros aventureiros. As terras do Conde da Ponte limitavam-se no município de Riachão do Jacuípe com as propriedades de João Veigas Peixoto, a terceira maior fortuna fundiária da Bahia no período colonial.

Dessas sesmarias foi desmembrada uma área de terra para João dos Santos Cruz, que a transformou numa fazenda de criação de gado denominada Riachão (IBGE, 2010, p. 01).

Do ponto de vista do povoamento, é bastante antigo e de acordo com Rios (2003), pode-se afirmar que parte da área dessa pesquisa era conhecida como Sertão dos Tocós não se sabe se devido ao nome de um rio próximo à Riachão do Jacuípe ou talvez pela suposta existência de um grupo indígena extinto, denominado Tocós, que teria inspirado o nome do rio. $O$ fato é que o primeiro registro histórico encontrado pela autora foi uma declaração das terras de Guedes de Brito em 1676, registrada na Revista do Instituto Geográfico e Histórico da Bahia (1916) apud Rios (2003, p.2021): “[...] entre os rios Jacuípe e Itapicuru, por eles acima, por serem os ditos Tocós muito faltos de água, haverem muitos matos, caatingas infrutíferas (...)".

Nota-se que o registro que trata da posse de terras no século XVII destaca a falta de água e a ocorrência de 'matos, caatingas infrutíferas'. Essa mentalidade prevaleceu até o século XXI, numa repetição de manejo das fazendas, semelhante ao que se realizou quando da ocupação da área, a partir da derrubada do 'mato' e da caatinga, considerada inútil.

Desde os escritos antigos, o sertão dos Tocós eram assim descritos: “Eis o que era o sertão dos Tocós em 1723. Uma porção de sítios de lavoura e criação, a pequena distancia uns dos outros (...) que separados por pequena distancia entre si, se ligavam pela comunidade de interesses de seus habitantes". (ARAUJO, 1926, citado por RIOS, 2003, p. 21).

Se o autor estiver correto, pode-se inferir que a sesmaria dos Tocós fora dividida em propriedades médias e pequenas, o que teria possibilitado o crescimento populacional verificado nessa área. Entretanto, é sabido que a realidade fundiária no século $X X$ e início do século $X X I$ tendeu à concentração das terras em poucas grandes propriedades.

As pastagens, notadamente voltadas à criação de bovinos, embora exista a criação de ovinos e caprinos, constituem-se na principal atividade rural dos municípios pesquisados.

Até mesmo estudiosos do semiárido brasileiro, destacam a importância da pecuária como 'única' atividade possível no período colonial, nas áreas de ocorrência de secas, a exemplo do que mencionou Campos (1996):

As condições adversas do Semi-árido, sujeito a secas periódicas, retardaram muito o início da ocupação portuguesa dos sertões. Até a primeira metade do século XVII, o domínio das áreas secas do interior do Nordeste, de Pernambuco ao Ceará, era dos índios. A partir de então e de forma bastante lenta, teve início o processo de ocupação, com o desenvolvimento da pecuária, única atividade possível na região das caatingas (CAMPOS, 1996, p. 265).

O resultado dessa 'racionalidade' na ocupação do espaço foi a redução da caatinga no médio Jacuípe, carente de estudos para constatar o seu estágio de desenvolvimento (primário ou secundário).

A respeito do processo de ocupação do nordeste brasileiro, Pinto (1984) destacou:

As vacas, os cavalos, as cabras e as ovelhas se interiorizaram, levadas pelos pastores que, num nomadismo conquistador, alcançaram novas áreas onde a vegetação nativa era o suporte alimentar, e a ação seletiva contínua dos animais recemintroduzidos iniciou um trabalho profíquo de quebra do equilíbrio ecológico. O índio, dominado, tornouse o vaqueiro exímio e adentrou com os rebanhos sob sua guarda os sertões ínvios que ele conhecia; o escravo negro foi trazido para as lides agrícolas e varou menos as caatingas, mas trouxe consigo, também, hábitos devastadores. Estava iniciada a verdadeira derrocada ecológica antrópica. (PINTO, 1984, p. 195)

Os caminhos do povoamento no século XVII, na Bahia, priorizavam os vales dos rios, conforme corroborado por SEI (2001). O caminho projetado a partir do rio Jacuípe, denota que as rotas de viagem prioritárias em estradas próximas aos leitos de rios começaram a ser estabelecidas há muitos anos, 
de modo que não se pode afirmar sem estudos botânicos que a cobertura vegetal da atualidade corresponde a caatingas primárias no médio Jacuípe, principalmente considerando-se que a prioridade da ocupação era derrubar a caatinga para 'beneficiar' a área, razão pela qual Pinto (op.cit) referiu-se a uma 'derrocada ecológica antrópica'.

De acordo com a SEI (2001), o processo de criação dos municípios cujas sedes situam-se no médio Jacuípe, Riachão do Jacuípe foi criado no início do século $X X$, em 1933 e desmembrou-se para a emancipação, entre 1985 a 1989 dos municípios de Pé de Serra, Capela do Alto Alegre, Gavião e Nova Fátima. Valente fora criado em 1958 e originou São Domingos em 1989. Retirolândia fora criado em 1962, enquanto São José do Jacuípe fora emancipado apenas em 1989. Portanto, Riachão do Jacuípe é o município mais velho do médio curso do Jacuípe, criado no início do século $X X$, enquanto Valente e Retirolândia emanciparam-se em meados do século XX e, por último, Pé de Serra, Capela do Alto Alegre, Gavião, Nova Fátima, São Domingos e São José do Jacuípe foram criados no fim do século XX.

Conforme demonstra a Tabela 01, a população por município no médio Jacuípe apresentou sensível declínio nos municípios criados entre 1985 e 1989, especialmente em Pé de Serra, Capela do Alto Alegre e Gavião, cuja perda da população absoluta se manteve entre 2000 a 2010, seguidas de São José do Jacuípe, Retirolândia, São Domingos e Nova Fátima (cujo decréscimo da população absoluta foi sensível entre 1990 e 2000, com pequena recuperação em 2010); o mesmo fenômeno foi observado em Riachão do Jacuípe, que sofrera diminuição de sua população absoluta na década de 1980 devido às emancipações de distritos mais dinâmicos, contudo sua população também declinou entre 1990 a 2000, com pequeno aumento em 2010. O município de Valente sofreu perdas populacionais na década de 1980 devido à emancipação de distrito, mas manteve entre a década de 1990 a 2010 o crescimento de sua população absoluta, o que está notoriamente relacionado à diferenciação socioeconômica

Tabela 01. População total nos municípios do médio Jacuípe (1970-2010).

\begin{tabular}{lccccc}
\hline \multicolumn{1}{c}{ Município } & \multicolumn{5}{c}{ Anos } \\
& 1970 & 1980 & 1991 & 2000 & 2010 \\
\hline Riachão do Jacuípe & 49864 & 62887 & 37610 & 31633 & 33172 \\
Valente & 16993 & 21791 & 17830 & 19145 & 24560 \\
Pé de Serra & & & 17048 & 13531 & 13752 \\
Retirolândia & 9019 & 10402 & 11300 & 10891 & 12055 \\
Capela do Alto Alegre & & & 17142 & 11898 & 11527 \\
São José do Jacuípe & & & 14100 & 9233 & 10180 \\
São Domingos & & & 10276 & 8526 & 9226 \\
Nova Fátima & & & 10445 & 7536 & 7602 \\
Gavião & & & 7118 & 4792 & 4561 \\
\hline
\end{tabular}

Fonte: https://sidra.ibge.gov.br/tabela/202\#resultado. Elaboração: Oriana Araujo. desse município em relação à sua hinterlândia, devido à ação da Associação dos Pequenos Agricultores do Estado da Bahia (APAEB), em Valente, conforme asseverou SANTOS (2007).

Inegavelmente, os municípios pesquisados possuem a sua gênese e desenvolvimento econômico associados à pecuária bovina extensiva e ao cultivo do sisal e produção de seus derivados. Esse fato foi confirmado em trabalho de campo nos municípios pesquisados, a partir da detecção de sisalais cultivados (Figura 04) e abandonados, bem como de pastagens em diferentes níveis de conservação/degradação.

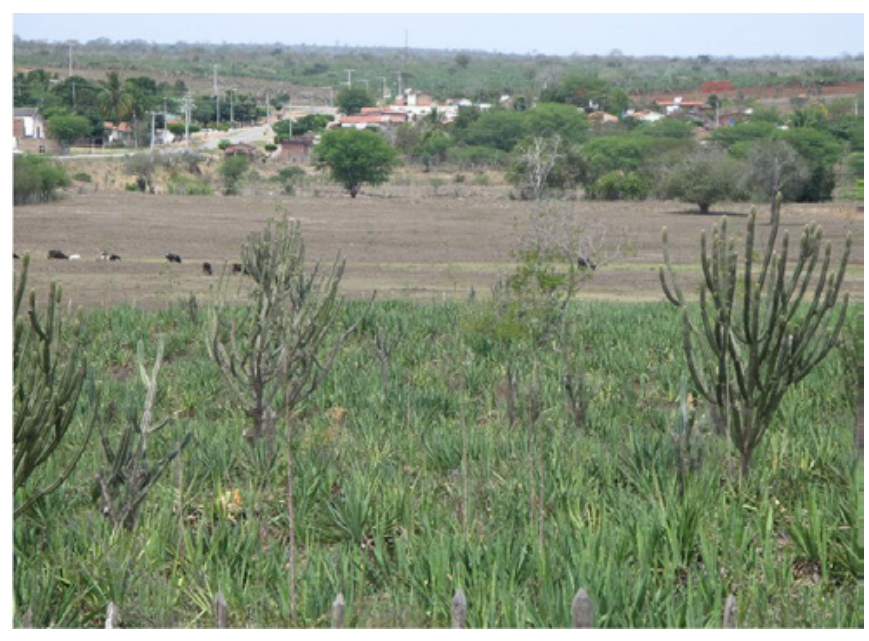

Figura 04. Aspecto de sisalal e pastagem nas margens do Rio Jacuípe. Distrito de Santo Antônio/São Domingos-BA (2010).

Nesse estudo a análise da produção agrícola é importante por comprovar o avanço ou redução dos principais tipos de cobertura do solo, haja vista a sensível diferença entre a existência de sisalais, caatinga ou pastagens para a cobertura vegetal e proteção dos solos, que influenciam diretamente nos processos erosivos e de percolação das águas no médio Jacuípe.

A criação do gado bovino de corte e para o leite é a principal atividade pecuária dos municípios pesquisadas e está associada a práticas agrícolas rudimentares, como a criação extensiva e retirada da cobertura vegetal original para a instalação de pastagens, que em períodos secos sofrem com o sobrepastoreio e tendem à exposição dos solos (salvo raras exceções), como já identificado e discutido por Ab'Sáber (1977), a respeito de práticas degradadoras e do processo de desertificação no nordeste semiárido:
[...] três séculos de atividades agrárias rústicas, centradas no pastoreio extensivo, e, algumas décadas de ações deliberadas de intervenção antrópica, com acentuado crescimento demográfico paralelo, terminaram por acrescentar feições de degradação pontuais, de fácil reconhecimento nas paisagens sertanejas, sob a forma de ulcerações dos tecidos ecológicos regionais (AB'SÁBER, 1977a, p.02-03).

Os dados relacionados à produção de bovinos (Gráfico 01) demonstram que houve sensível aumento da produção 
de bovinos por cabeça entre 1995 a 2015 nos municípios de Riachão do Jacuípe (acréscimo de 167\%), Pé de Serra (acréscimo de 102\%), Capela do Alto Alegre (36\%), Nova Fátima (154\%) e Gavião (62\%); São José do Jacuípe expandiu muito a produção entre 1995 a 2005 (406\%), com pequena redução entre 2005 a 2015 (8,8). Já nos municípios de Valente e Retirolândia houve redução, de $155 \%$ e $47 \%$ respectivamente, do rebanho bovino entre 1995 a 2015, enquanto São Domingos decresceu apenas $13 \%$ da sua produção bovina entre 1995 a 2015.

Gráfico 01. Efetivo do rebanho bovino (cabeças) nos municípios do médio Jacuípe (1975-2015)

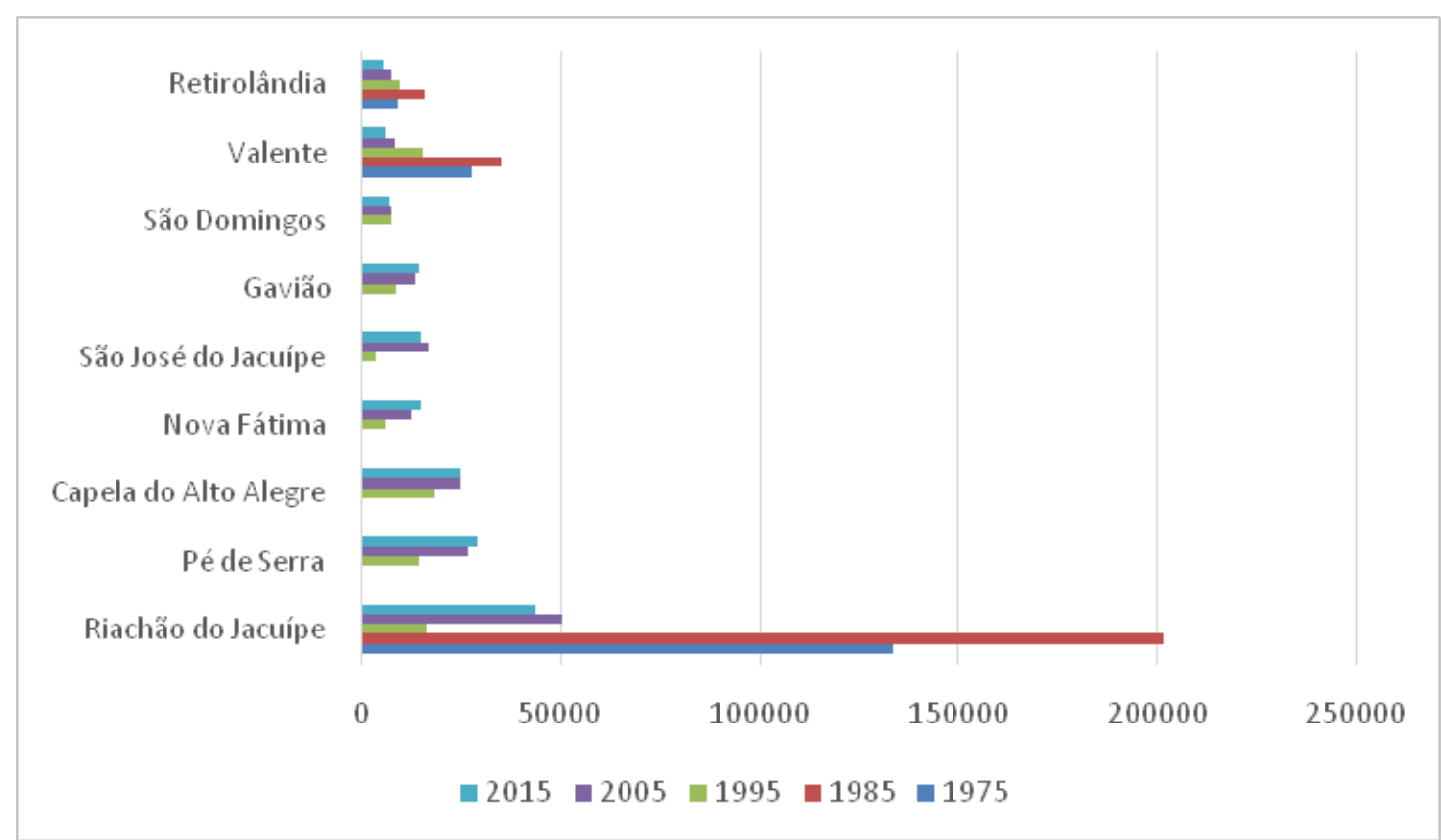

Fonte: https://sidra.ibge.gov.br/tabela/3939\#resultado. Elaboração: Oriana Araujo.

Os dados sobre o sisal produzido nos municípios pesquisados (Gráfico 02) demonstram que entre 2005 e 2015 houve sensível redução na produção de sisal nos municípios de Riachão do Jacuípe, Nova Fátima, Capela do Alto Alegre, Gavião, Pé de Serra e São José do Jacuípe, que reduziram a zero ou produziram até 304 toneladas de sisal no ano de 2015, enquanto em São Domingos houve uma redução de quase metade da pro- dução entre 2005 e 2015, mesmo assim, mantendo a expressividade relativa de 2700 toneladas produzidas em 2015 . Já Valente e Retirolândia, cresceram a quantidade de sisal produzida entre 2005 e 2015: Valente passou de 6500 toneladas produzidas em 2005 para 13500 toneladas de sisal produzidas em Valente em 2015, enquanto Retirolândia saltou de 3500 toneladas em 2005 para 6552 toneladas de sisal produzidas em 2015.

Gráfico 02. Sisal produzido (toneladas) nos municípios do médio Jacuípe (1975-2015)

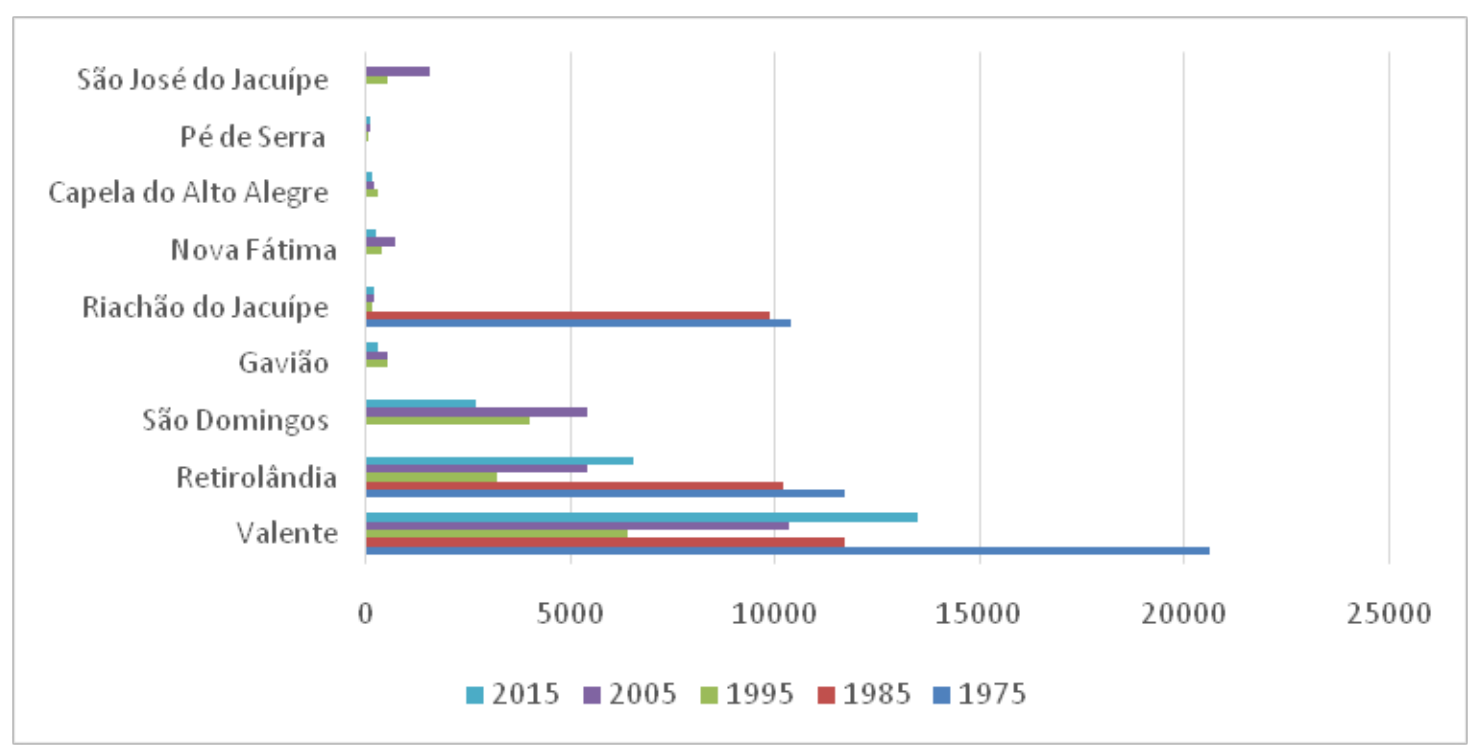

Fonte: https://sidra.ibge.gov.br/tabela/5457\#resultado. Elaboração: Oriana Araujo. 
No item seguinte serão examinadas as possíveis relações entre a cobertura vegetal das cidades e seus entornos mais imediatos, no intuito de explicar as possíveis causas para a variação da intensidade do desmatamento e da cobertura vegetal, correlacionado os dados sobre população, quantidade de sisal produzida e a quantidade do rebanho bovino ao longo das últimas décadas nesses municípios.

Área urbanas, entorno e cobertura vegetal no médio Jacuípe: indicadores da degradação ambiental

Na verificação sobre a interferência das áreas urbanas do médio Jacuípe no processo de degradação ambiental, foram consideradas as sedes de município e sua influência imediata e até $5 \mathrm{~km}$, porque apesar de tratar-se de centros urbanos relativamente pequenos e fortemente atrelados ao campo, considerou-se que há fatores que maximizam a intensificação do uso agrícola dos solos próximos aos centros urbanos, de modo que, em trabalhos de campo houve dificuldade de encontrar remanescentes de caatinga em áreas próximas às cidades. É preciso considerar ainda que essas terras são valorizadas, com preços mais elevados que as terras mais distantes das áreas urbanas.

O tecido socioespacial urbano é tão dinâmico quanto a sociedade que aí imprime suas marcas, havendo diferenças muito sensíveis no que tange à cobertura vegetal nas áreas próximas às sedes municipais pesquisadas.

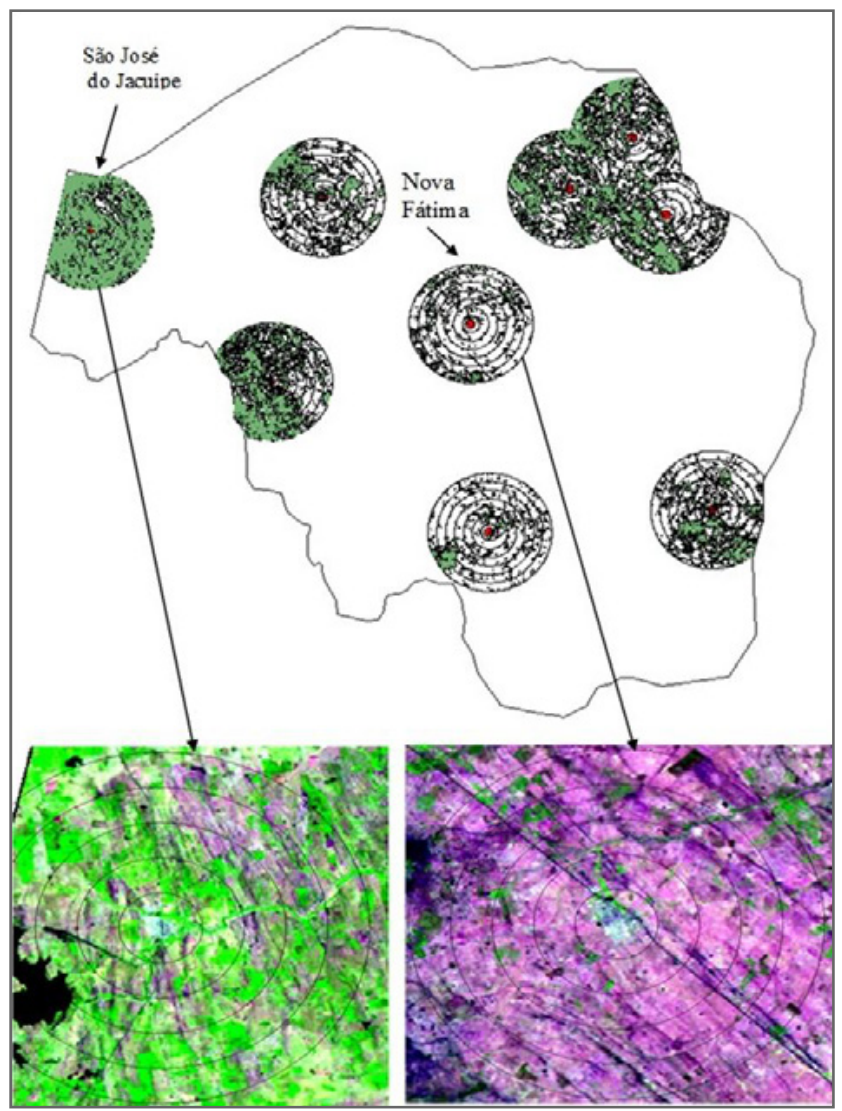

Figura 05. Comparação da cobertura vegetal dos mapas de distância das sedes do médio Jacuípe. Detalhe: projeção dos buffers na imagem de satélite das cidades de São José e Nova Fátima
A combinação entre o mapa de cobertura vegetal (caatinga primária e/ ou secundária, sisal, palma, pastagem verde) elaborado a partir de técnicas de processamento digital de imagens do satélite Landsat TM 5 (ARAUJO DA SILVA, 2010) e um mapa de distâncias (buffers), produzido a partir das áreas urbanas, demonstrou a nítida diferença entre as cidades cujo entorno possui mais cobertura vegetal (em verde) em detrimento das cidades que os solos estão mais exposto, a exemplo de São José do Jacuípe e Nova Fátima, como evidenciado no detalhe da imagem de satélite (Figura 05).

A partir das técnicas de Processamento Digital de Imagens (PDI) de satélite, foi possível calcular o percentual de cobertura vegetal num raio de $5 \mathrm{~km}$ desde a sede. Das cidades pesquisadas, constatou-se uma média de $11 \%$ de cobertura vegetal na sede e entorno urbano (até $5 \mathrm{~km}$ ) das nove cidades que compõem o médio Jacuípe. Conforme demonstrado no Gráfico 04, abaixo dessa média, situaram-se as cidades com menor cobertura vegetal: Nova Fátima e Pé de Serra (apenas $3 \%)$, enquanto Gavião possui $9 \%$ de cobertura vegetal, seguido por Valente e Riachão do Jacuípe (ambas com 10\% de cobertura vegetal). No grupo das cidades com um pouco mais de cobertura vegetal no médio Jacuípe, situando-se na média e acima da média, encontram-se Retirolândia com $11 \%$ de cobertura vegetal, São Domingos com 14\%, Capela do Alto Alegre com $16 \%$ de cobertura vegetal, enquanto São José do Jacuípe distoa do conjunto, apresentado $24 \%$ de cobertura vegetal até $5 \mathrm{~km}$ da sede.

Gráfico 04. Percentual de cobertura vegetal das cidades do médio Jacuípe até $5 \mathrm{~km}$.

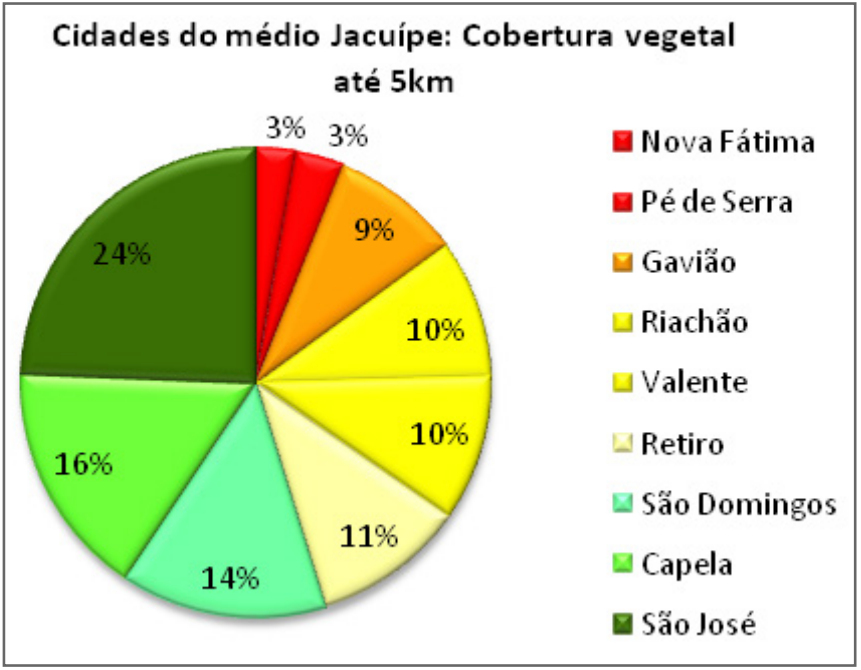

Fonte: Mapa de cobertura vegetal de 2008, a partir do Landsat TM 5, elaborado pela autora (ARAUJO DA SILVA, 2010, p.123).

A busca de explicações factuais para a variação tão grande do percentual de cobertura vegetal no entorno até $5 \mathrm{~km}$ das cidades do médio Jacuípe, desde $3 \%$ de cobertura em Nova Fátima e Pé de Serra até $24 \%$ em São José do Jacuípe, remeteu às seguintes hipóteses: 
1. As cidades de ocupação mais antiga e com intensificação do uso do solo do entorno, aliado ao processo de ocupação baseado em técnicas agrícolas rudimentares, favoreceram o processo de desmatamento nas cidades mais velhas em relação às mais novas;

2. As cidades, ainda que sejam pequenas e possuam manchas urbanas menores favorecem o desmatamento no seu entorno imediato, por facilitar o acesso ao campo e a intensificação dos fluxos relacionados essencialmente ao transporte;

3. O tipo de uso agrícola do solo deve potencializar ou mitigar o desmatamento;

4. Há alguma diferença na percepção ambiental por parte da população e gestores, que propiciam um uso diferenciado do solo, mantendo ou retirando sua cobertura vegetal.

Entretanto, as evidências resultantes da análise dos dados e trabalhos de campo não permitiram a validação de todas essas hipóteses, porque, dentre outras razões:

1. Riachão do Jacuípe é a mais antiga cidade, seguida - com uma diferença de cerca de cerca de 25 anos de Valente e Retirolândia e, situam-se na média da cobertura vegetal do conjunto analisado (como Retirolândia, com 11\% de cobertura vegetal) ou pouco abaixo da média (Riachão do Jacuípe e Valente possuíam $10 \%$ de cobertura vegetal). A pior cobertura vegetal está em Nova Fatima e Pé de Serra (ambas com apenas 3\% de cobertura vegetal) que são cidades criadas nos meados e fins dos anos 1980.

Portanto, pode-se afirmar que o ano de emancipação das cidades do médio Jacuípe não é fator fundamental no avanço do desmatamento de seu entorno imediato (até $5 \mathrm{~km}$ ).

2. De modo geral, observou-se em campo que a maioria das cidades são pequenas (com exceção de Riachão do Jacuípe) e sua dinâmica socioeconômica é muito integrada ao campo e, na análise das imagens de satélite percebeu-se que havia maior densidade vegetal afastando-se das áreas urbanas. $O$ cálculo da distribuição por quilômetro da cobertura vegetal já incipiente, em relação à sede urbana demonstrado em Araujo da Silva (2010, p.125) e exemplificado a partir dos gráficos 05 e 06 que ilustram a distribuição da cobertura vegetal em Nova Fátima (de um total de 3\%) e São José do Jacuípe (de um total de $24 \%$ ), evidenciou que há pouca cobertura vegetal até $2 \mathrm{~km}$ em todas as cidades pesquisadas, com pequenas variações, havendo aumento progressivo a partir de $3 \mathrm{~km}$, com concentração da cobertura vegetal entre 4 a km de distância das sedes.

É plausível considerar que o entorno imediato das cidades do médio Jacuípe (até $3 \mathrm{~km}$ ) sofre uma pressão maior no uso do solo sendo, portanto, mais desmatado em relação às áreas mais distantes das cidades. Não obstante, é possível afirmar ainda que há forte desmatamento até $5 \mathrm{~km}$ das cidades do médio Jacuípe, haja vista a média de apenas $11 \%$ de cobertura vegetal das sedes urbanas até a referida distância.

3. O trabalho de campo para coleta de dados de cobertura vegetal para verificação em Processamento Digital de
Imagens, evidenciou maior exposição dos solos nas áreas de pastagem, enquanto as áreas de plantação de sisal oferecem mais cobertura. Tratam-se das atividades agrícolas predominantes no médio Jacuípe. Conforme explicitado no item anterior, os dados agrícolas demonstraram que Riachão do Jacuípe, Nova Fátima, Capela do Alto Alegre, Gavião, Pé de Serra e São José do Jacuípe reduziram significativamente a produção de sisal desde 1975 a 2015 (que já não produziam expressivamente), optando pela pecuária que teve forte incremento no mesmo período; opostamente, nos municípios de Valente e Retirolândia, houve forte redução do rebanho bovino e recuperação da produção de sisal; em São Domingos houve redução na produção de sisal, mas com produção ainda expressiva, associada à manutenção do rebanho bovino. Pode-se afirmar que os municípios de médio Jacuípe que optaram pela manutenção dos sisalais possuem uma média de $13,7 \%$ de cobertura vegetal no entorno das sedes urbanas até $5 \mathrm{~km}$, enquanto os municípios bovinocultores possuem uma média de $10,8 \%$ de cobertura vegetal no entorno das sedes urbanas até $5 \mathrm{~km}$. Embora representem médias e não as especificidades, é importante ressaltar que os municípios sisaleiros possuem cobertura vegetal mediana, enquanto os bovinocultores apresentam os extremos: de apenas 3\% de cobertura em Pé de Serra e Nova Fátima, a 24\% de cobertura em São José do Jacuípe. A explicação parcial para essa disparidade foi resolvida em campo, ao constatar-se forte presença da algaroba (prosopis juliflora) na recomposição da cobertura vegetal em São José do Jacuípe, Nova Fátima, Gavião e Riachão do Jacuípe. A algaroba é uma espécie oportunista e sua expansão descontrolada pode impedir o crescimento da vegetação nativa, o que é perigoso para a manutenção e recomposição da caatinga no médio Jacuípe (ARAUJO DA SILVA, 2010).

Claro que a cobertura vegetal original, da caatinga primária ou secundária corresponde à melhor proteção do solo e manutenção do hábitat de diversas espécies, mas sua ocorrência no médio Jacuípe é pontual, como demonstrado em estudo que constatou um alto grau de susceptibilidade à degradação ambiental na área, devido à retirada da cobertura vegetal original e forte exposição dos solos (ARAUJO DA SILVA, 2010); o percentual de cobertura vegetal no entorno das cidades foi uma das variáveis consideradas, mas sem explicar detalhadamente os elementos e relações causais da sua ocorrência.

A análise da cobertura vegetal por $\mathrm{km}$ a partir da sede urbana pode ser utilizada como indicador progressivo de aumento ou diminuição da susceptibilidade à degradação ambiental, a partir de técnicas de modelagem espacial como a inferência fuzzy ou lógica nebulosa, conforme demostrado em Araujo da Silva (2010) e Araujo, Chaves e Franca-Rocha (2013), colaborando para a compreensão da influência da ocupação urbana na degradação do ambiente. 
Gráfico 05. Nova Fátima: Percentual de cobertura vegetal em relação à sede urbana (de 1 a $5 \mathrm{~km}$ ).

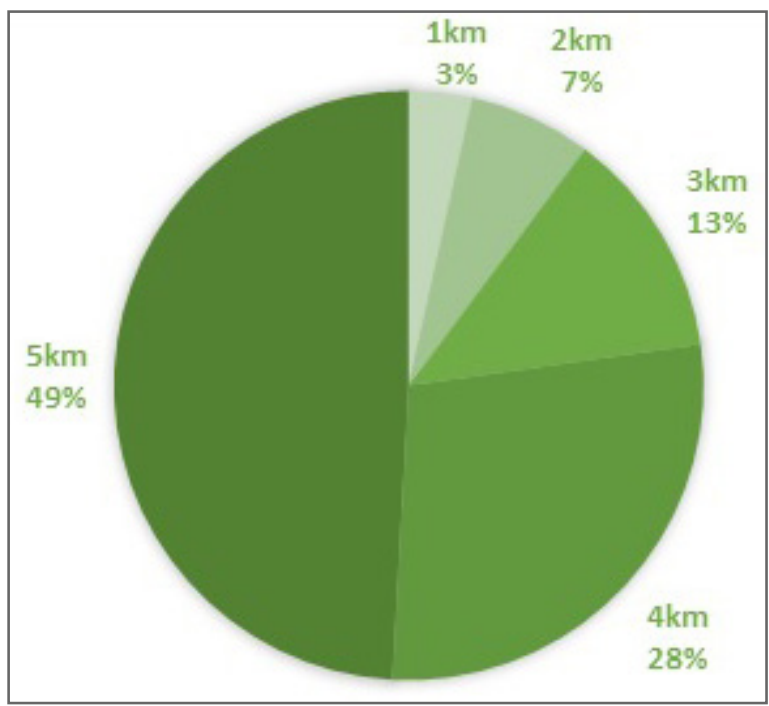

Gráfico 06. São José do Jacuípe: percentual de cobertura vegetal em relação à sede urbana (de 1 a $5 \mathrm{~km}$ ).

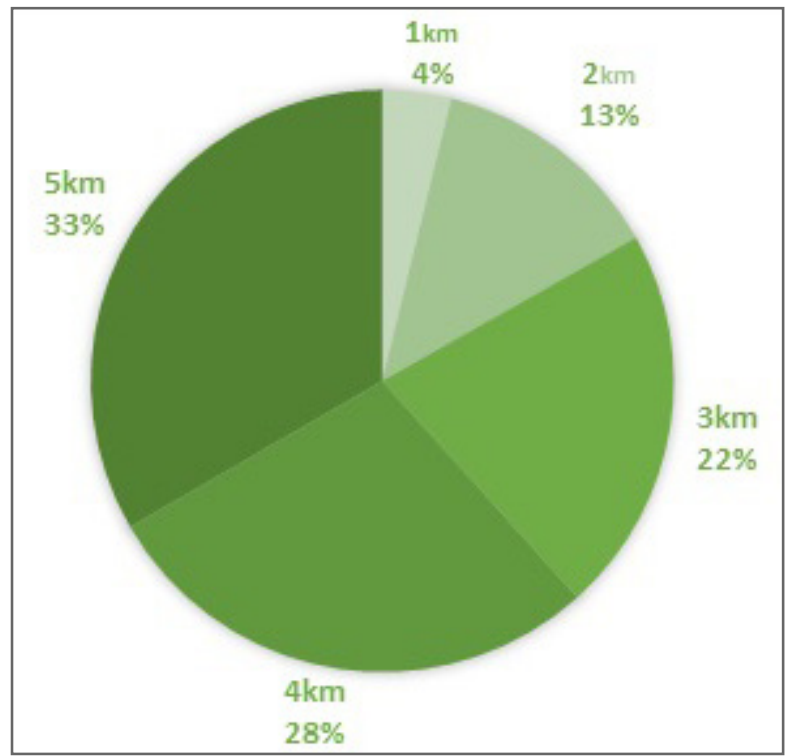

\section{Conclusão}

A análise da influência de cidades do médio Jacuípe no processo de retirada da cobertura vegetal no médio Jacuípe permitiu afirmar que o tamanho das cidades não é fator preponderante para o aumento ou diminuição da cobertura vegetal em suas áreas urbanas diretas e no seu entorno imediato, haja vista que as menores coberturas vegetais, de apenas 3\% (até $5 \mathrm{~km}$ ) foram encontradas em Pé de Serra e Nova Fátima, que são muito pequenas se comparadas a Riachão do Jacuípe e Valente. $O$ fato das cidades serem mais antigas que outras também não amplia o desmatamento em seu entorno imediato, conforme reiterado pelo mesmo exemplo.

Outrossim, constatou-se que as cidades avaliadas podem ser subdivididas em dois grupos: o grupo de cidades sisaleiras, composto por Valente, Retirolândia e São
Domingos; e o grupo de cidades bovinocultoras, composto por Riachão do Jacuípe, Capela do Alto Alegre, São José do Jacuípe, Nova Fátima, Gavião e Pé de Serra. Na média, há $13,7 \%$ de cobertura vegetal no entorno das sedes urbanas até $5 \mathrm{~km}$ dos municípios sisaleiros, enquanto os municípios bovinocultores possuem uma média de 10,8\% de cobertura vegetal no entorno das sedes urbanas até $5 \mathrm{~km}$ e as cidades mais desmatadas do conjunto: Pé de Serra e Nova Fátima.

Conclui-se que as cidades do médio Jacuípe e seu entorno imediato possuem pouca cobertura vegetal (apenas $11 \%)$, devido a diferentes fatores, tanto relacionados ao próprio adensamento da mancha urbana e pouca arborização das cidades, quanto do uso intensivo dos solos em propriedades rurais próximas às cidades, que estão mais descobertos na bovinocultura do que pelos sisalais, sendo um indicador importante de degradação ambiental.

A retirada da cobertura vegetal expõe os solos e intensifica o processo erosivo, já muito forte quando da ocorrência das chuvas torrenciais próprias do clima semiárido, o que conduz ao assoreamento da rede hídrica da bacia do Rio Jacuípe. Além disso, é importante destacar o processo de empobrecimento dos solos, bem como a extinção de hábitats e de espécies que deles dependem para a sobrevivência, como melhor explicitado em Araujo (2013).

Claro que é preciso buscar conciliar a necessidade humana de moradia e a manutenção da qualidade ambiental nas cidades e seus entornos, tanto para a garantia do funcionamento do sistema natural, quanto para a qualidade da vida humana. Para as cidades pesquisadas e outras do semiárido baiano que estão em situação semelhante indica-se a instalação de parques/jardins urbanos plantados com espécies da caatinga, especialmente no Sudeste das cidades, a fim de auxiliar na diminuição do calor nessas cidades e na manutenção de hábitats. Outras medidas como o plantio de árvores adequadas aos espaços urbanos também podem contribuir.

É preciso que o planejamento urbano seja feito com mais atenção, de modo que as ruas sejam mais largas, com espaço nas calçadas para o plantio de árvores, bem como para a circulação das pessoas, com intuito de que as cidades sejam agradáveis para a realização de caminhadas e passeios.

Nos espaços rurais é fundamental ainda a destinação de $20 \%$ da área da propriedade rural para o estabelecimento da reserva legal para proteção da vegetação e de hábitats, conforme indicado no código florestal brasileiro (BRASIL, 2012) e de $30 \mathrm{~m}$ das matas ciliares (vegetação das margens dos rios) e de reservatórios resultantes de barramentos dos rios, mas sistematicamente ignorados tanto pela maioria dos produtores rurais, como pelos gestores dos municípios do médio Jacuípe.

Indica-se a instalação de unidades de conservação, bem como de campanhas de conscientização dos produtores rurais, a fim de que atuem na mitigação de danos ambientais em suas propriedades, bem como do estabelecimento de mecanismos de fiscalização pelos poderes municipal e estadual. Afinal, conforme diz o poeta Vital Farias (1984), “[...] O que se 
corta em segundos gasta tempo prá vingar/ e o fruto que dá no cacho prá gente se alimentar?/ depois tem o passarinho, tem o ninho, tem o ar [...]" e tem a responsabilidade socioambiental com as futuras gerações que têm direito a um ambiente agradável e adequado para viver.

\section{Referências}

ARAUJO DA SILVA, O. Médio curso da bacia do rio Jacuípe, Bahia: proposta metodológica para estimativa de susceptibilidade à degradação ambiental. Feira de Santana: PPGM/ UEFS, 2010. (Dissertação de mestrado).

ARAUJO, O. Era uma vez na Bahia uma bonita floresta: degradação ambiental no médio curso da bacia hidrográfica do rio Jacuípe. Sitientibus. Feira de Santana, n. 48, p.49-72, jan./jun. 2013.

ARAUJO, O; CHAVES, J. M; FRANCA-ROCHA, W. de J. S. Proposta metodológica para modelagem espacial da susceptibilidade à degradação ambiental por inferência fuzzy aplicada ao Médio Jacuípe-BA. Revista Brasileira de Cartografia, Rio de Janeiro, N 10410 65/6, p. 1025-1043, Nov/Dez/2013.

ARAUJO, G. H. de S.; ALMEIDA, J. R. de.; GUERRA, A. J. T. Gestão ambiental de áreas degradadas. $3^{\text {a }}$ ed. Rio de Janeiro: Bertrand Brasil, 2008.

AB'SÁBER, A. N. (a) Problemática da desertificação e da savanização no Brasil intertropical. Geomorfologia, vol. 53, 1-19. São Paulo: Universidade de São Paulo, Instituto de Geografia, 1977.

ALMEIDA, M. J. C. P. de. Meio ambiente e o mundo rural. In: LEITE, J. L. (Org.). Problemas-Chave do Meio Ambiente. Salvador: Inst. de Geociências da UFBA, 1994.

BRASIL. LEI № 12.651, de 25 de maio de 2012 (Código Florestal Brasileiro). 2012. Disponível em: http://www.planalto.gov. br/ccivil_03/_Ato2011-2014/2012/Lei/L12651.htm.

CAMPOS, J. N. B. Vulnerabilidades hidrológicas do semi-árido às secas. Planejamento e políticas públicas. № 16, dez de 1996.

CRÓSTA, Alvaro P. Processamento Digital de Imagens de Sensoriamento Remoto. Campinas/São Paulo: IG/UNICAMP, 1992.

DRURY, S. A. A Guide to Remote Sensing: Interpretting Imagens of the Earth. Oxford University Press: Oxford, 1990.

FARIAS, Vital. Saga da Amazônia. In: Cantoria 1 (LP). Kuarup, 1984. Disponível em: https://geraldoazevedo.com.br/musicas/ cantoria-1/.

GREGORY, K. J. A natureza da geografia física. Rio de Janeiro: Bertrand Brasil, 1992.

GUERRA, A. J. T. e BOTELHO, R. G. M. Erosão dos solos. In: CUNHA, S. B. e GUERRA, A. J. T. (Orgs.). Geomorfologia do Brasil. Rio de Janeiro: Bertrand Brasil, 1998.

IBGE (Instituto Brasileiro de Geografia e Estatística). Riachão do Jacuípe. Disponível em: http://biblioteca.ibge.gov.br/ visualizacao/ dtbs/bahia/riachaodojacuipe.pdf. Acesso em abril de 2010.

IBGE (Instituto Brasileiro de Geografia e Estatística). Manual Técnico da Vegetação Brasileira. Rio de Janeiro: IBGE, 1992.

JENSEN, John R. Remote Sensing of the Environment: An Earth Resource Perspective. 2ª ed. Upper Saddle River: Pearson Prentice Hall, 2007.

LILLESAND, Thomas M; KIEFER, Ralph W. Remote Sensing and Image Interpretation. 6. ed. New York: John Wiley, 2008.

LIU, Willian Tsé. Aplicações de sensoriamento remoto. Campo Grande: Ed. UNIDERP, 2006.

MUSTARD, John F. e SUNSHINE, Jessica M. Spectral Analysis for Earth Science: Investigations Using Remote Sensing Data. In: RENCZ, Andrew N (Org.). Remote sensing for the Earth Sciences. John Wiley \& Sons, Inc: New York, 1999.

NOVO, Evlyn M. L. de M. Sensoriamento Remoto: Princípios e Aplicações. 2a ed. São Paulo: Edgard Blucher, 1995.

PINTO, G. C. P. Manejo ecológico da caatinga. Simpósio sobre caatinga e sua exploração racional (Anais). Feira de Santana: UEFS, 1984.

RIOS, I. N. A. Nossa Senhora da Conceição do Coité: poder e política no século XIX. Salvador: Universidade Federal da Bahia, 2003. (dissertação de mestrado). Disponível em: http://www. ppgh.ufba.br/IMG/pdf/Nossa_Sra_da_Conceicao_do_Coite.pdf.

SANTOS, M. Por uma outra globalização: do pensamento único à consciência universal. 9ạed. Rio de Janeiro: Record, 2002.

SANTOS, E. M. Associativismo e territorialidade na região sisaleira da Bahia: relações com o desenvolvimento. Sergipe: UFS, 2007. (Tese de doutorado).

SEI (Superintendência de Estudos Econômicos e Sociais da Bahia). Evolução territorial e administrativa do Estado Bahia: um breve histórico. Salvador: SEI, 2001.

SILVA, J. M .C. da; TABARELLI, M.; FONSECA, M. T.; LINS, L. V. (Orgs.). Biodiversidade da caatinga: áreas prioritárias para a conservação. Brasília, DF: Ministério do Meio Ambiente: Universidade Federal de Pernambuco, 2004.

Sistema IBGE de Recuperação Automática - SIDRA. Pesquisa Agrícola Municipal. Disponível em: https://sidra.ibge.gov.br/ pesquisa/pam/tabelas.

Sistema IBGE de Recuperação Automática - SIDRA. Pesquisa da Pecuária Municipal. Disponível em: https://sidra.ibge.gov. br/pesquisa/ppm/quadros/brasil/2017.

SOUSA, C. L. de. Avaliação da pressão antrópica sobre a cobertura vegetal nos municípios de Cedro e Solidão (sertão pernambucano) com o uso de imagens TM Landsat e Sistemas de Informações Geográficas. São José dos Campos: INPE, 2003.

STRAHLER, A. N.; STRAHLER, A. H. Geografia fisica. 3. Ed. Barcelona: Omega, 1989. 